\title{
Lipophilic Inducers Extracted from Corallina pilulifera for Larval Settlement and Metamorphosis of Two Sea Urchins Pseudocentrotus depressus and Anthocidaris crassispina ${ }^{* 1,2}$
}

\author{
Hitoshi Kitamura, ${ }^{* 3}$ Shigeru Kitahara, ${ }^{* 3}$ and Kazutugu Hirayama ${ }^{* 3}$ \\ (Received April 15, 1991)
}

\begin{abstract}
Lipophilic extracts from the coralline alga Corallina pilulifera which induced settlement and metamorphosis of fully developed 8-armed larvae of Pseudocentrotus depressus and Anthocidaris crassispina, were found by a simple bioassay method. Benzene, ether, and methanol extracts from the alga also had an inducing effect. Column chromatography showed that simple lipids such as hydrocarbons, triglycerides, and free fatty acids were the inducers. Glycolipid and phospholipid did not induce settlement or metamorphosis.
\end{abstract}

The sea urchin "Akauni" Pseudocentrotus depressus is an important species for the fisheries industry in the west part of Japan. For example, the fish farming centers in Saga and Nagasaki Prefectures prepare by means of artificial fertilization, about one million seeds of $P$. depressus (5-10 $\mathrm{mm}$ in test diameter) every year, for promoting starting stock in the holding area. "Murasakiuni" Anthocidaris crassispina is also popular, but only a small number of seeds are produced in the above centers.

Fully developed, 8-armed larvae of $P$. depressus and A. crassispina do not metamorphose in a clean beaker, but show high rates of metamorphosis upon contact with benthic diatoms, algae such as "Hiziki" Hizikia fusiformis and "Umitoranoo" Sargassum thunbergii, and both crustose and foliose coralline algae. ${ }^{1-3)}$

Field observations showed that newly settled individuals of sea urchins Strongylocentrotus purpuratus and $S$. franciscanus form dense populations on rocky areas covered with crustose coralline algae.) Metamorphosis of these larvae and Loxechinus, Lytechinus, and Arbacia larvae can also be induced by a bacterial film on a solid substrate. ${ }^{5-7)}$

These studies led us to examine the assumption that diatoms, bacterial film and some kinds of algae possess chemical inducers of settlement and metamorphosis of sea urchin larvae. How- ever, there are only two reports on such chemical inducers. Cameron and Schroeter ${ }^{6)}$ studied a chemical inducer from bacteria, and Pearce and Scheibling ${ }^{\mathrm{B})}$ indicated that aqueous extracts of coralline algae can induce metamorphosis of $S$. droebachiensis larvae. In neither study were the chemical characteristics of these inducers made clear.

We have studied lipophilic and water soluble substances extracted from the foliose coralline alga Corallina pilulifera to clarify the chemical inducers of larval settlement and metamorphosis of $P$. depressus and $A$. crassispina. In this paper we describe the results obtained for lipophilic inducers.

\section{Materials and Methods}

Test Larvae

$P$. depressus and A. crassispina larvae, cultured to the 8-armed stage with a fully developed urchin rudiment, were used in the experiments. After fertilization, $P$. depressus larvae were cultured for about three weeks at $17 \sim 22^{\circ} \mathrm{C}$ in the laboratory. 8-armed larvae were also obtained from the fish farming centers in Saga Prefecture and Nagasaki city. A. crassispina larvae were cultured for about two weeks at $22 \sim 25^{\circ} \mathrm{C}$ in the laboratory. The diatom Chaetoceros gracilis was used as food for these larvae.

*1 This work was supported by grants from the Ministry of Education, Science, and Culture of Japan.

*2 The outline of this report was presented at the autumn meeting of Japan. Soc. Sci. Fish., Nara, 1990.

*3 Faculty of Fisheries, Nagasaki University, Nagasaki 852, Japan (北村 等, 北原茂, 平山和炊：與崎 大学水産学部). 
Extraction and Fractionation of Lipophilic Substances

The foliose coralline alga Corallina piluifera was collected from the rocky shore near the Fish Farming Center in Saga. The alga $(5 \mathrm{~g}$, wetweight) was air-dried for one day, and soaked in $100 \mathrm{~m} /$ of benzene at room temperature for a similar period. The solvent was decanted and evaporated to dryness. The ether and methanol extracts were also obtained in the same manner.

Alga $(800 \mathrm{~g}$, wet-weight) was air-dried for one day and soaked in chloroform-methanol $(2: 1,1,000 \mathrm{~m} /)$ for two days. The solvent was decanted and soaking repeated three times. The combined extracts were shaken with water (about $600 \mathrm{ml}$ ) to obtain both lipophilic and watersoluble substances. The organic layer was evaporated to dryness, to yield about $3,600 \mathrm{mg}$ (about $4.5 \mathrm{mg}$ per $1 \mathrm{~g}$ of wet-weight).

A portion of the crude lipid ( $30 \mathrm{mg}$ ) was subjected to silica gel column chromatography (Mallinckrodt 100 mesh, $(\phi 2 \times 18 \mathrm{~cm})$, packed with chloroform). The elution was made as follows; chloroform (200 m/, Fraction-1, F-2), acetone $(100 \mathrm{~m} /, \mathrm{F}-3)$, methanol $(100 \mathrm{~m} /, \mathrm{F}-4)$, and $10 \%$ aq. methanol $(100 \mathrm{~m} /$, F-5). Each elute was evaporated to dryness at $36^{\circ} \mathrm{C}$ and redissolved in less than $3 \mathrm{~m} /$ of chloroform. Thin-layer chromatography (TLC) of these five fractions was performed on silica gel plates (Whatman, 60A, $0.25 \mathrm{~mm}$ thickness $20 \times 20 \mathrm{~cm}$ ) with chloroformacetone $(=9: 1$ or $1: 1)$. Lipids on the plates were visualized by spraying with $50 \% \mathrm{H}_{2} \mathrm{SO}_{4}$, anthrone, and Dittmer reagents.

\section{Bioassay Method}

The three organic solvents extracted, the lipid extracted with chloroform-methanol and the fractions, F-1 F-5, were bioassayed for the effect on settlement and metamorphosis of the two species of sea urchin larvae.

Whatman chromatography paper $(46 \times 57 \mathrm{~cm})$ was used for the bioassay substrate. The paper was cut into circles of $5 \mathrm{~cm}$ diameter (about $20 \mathrm{~cm}^{2}$ ). Each cxtract or fraction in chloroform was adsorbed on the paper, and the organic solvent was evaporated off in a draft. The paper with adsorbed lipophilic substances was set on the bottom of a $200 \mathrm{~m} /$ Pyrex beaker, and $100 \mathrm{~m} /$ of filtered seawater (Whatman glass fiber filter, $\mathrm{GF} / \mathrm{C}$ ) was poured into the beaker. After that, thirty 8-armed larvae of $P$. depressus or $A$. crassispina were placed into the beaker. Paper with adsorbed organic solvent only was used as a control. The beakers were kept at $22^{\circ} \mathrm{C}$ in a dark room. After $24 \mathrm{~h}$, the state of each larva was checked by stereoscopic microscope.

Assessment of the effect on the settlement and metamorphosis was made on the basis of settlement rate and metamorphosis rate. The former was expressed as the percentage consisting of individuals which are partially metamorphosed larvae (with extruded feet, but which still had larval cilia) and juvenile sea urchin. The latter was the percentage of individuals which had undergone full metamorphosis to the juvenile sea urchin form.

\section{Results}

When the fresh, foliose coralline alga $(5 \mathrm{~g}$, wet-weight) was placed into $100 \mathrm{~m} /$ filtered seawater in a $200 \mathrm{~m} /$ beaker, more than $90 \%$ of the 8-armed larvae of both sea urchin species metamorphosed within $24 \mathrm{~h}$.

The settlement and metamorphosis rates in the benzene, ether, and methanol extracts are shown in Table 1. More than $80 \%$ of both species larvae settled in response to the presence of these extracts. Although the metamorphosis rate in benzene extract was $4 \%$, the ether and methanol extracts induced metamorphosis in about $90 \%$ of $P$. depressus larvae, and about $70 \%$ of A. crassispina larvae. Throughout all of the experiments, the settlement and metamorphosis rates of the control tests were lower than $15 \%$ and $0 \%$, respectively.

Table 2 shows the effect of the lipids extracted with chloroform-methanol (2:1). All $P$. depressus larvae settled with a dose of more than $10 \mathrm{mg}$ lipid/paper, whereas $87 \%$ metamorphosed with

Table 1. Induction of settlement and metamorphosis of $P$. depressus and $A$. crassispina larvae by extracts from $5 \mathrm{~g}$ (wet weight) of the foliose coralline alga Corallina pilulifera

$$
\text { (\%) }
$$

\begin{tabular}{clcc}
\hline Sea urchin & Extract & $\begin{array}{c}\text { Settlement } \\
\text { Rate }\end{array}$ & $\begin{array}{c}\text { Metamor- } \\
\text { phosis } \\
\text { Rate }\end{array}$ \\
\hline $\begin{array}{clcc}\text { Psendocentrotus } \\
\text { depressus }\end{array}$ & $\begin{array}{l}\text { Benzene } \\
\text { Ether }\end{array}$ & 80 & 4 \\
& Methanol & 100 & 93 \\
Anthocidaris & (Control) & $<15$ & 87 \\
crassispina & Benzene & 100 & 0 \\
& Ether & 100 & 67 \\
& Methanol & 100 & 70 \\
& (Control) & $<15$ & 0 \\
\hline
\end{tabular}


Table 2. Induction of settlement and metamorphosis of $P$. depressus and $A$. crassispina larvae by the lipid extracted with chloroform-methanol (2:1) from the foliose coralline alga Corallina pilulifera

\begin{tabular}{lccc}
\hline Sea urchin & $\begin{array}{c}\text { Lipid } \\
\text { (mg/paper) }\end{array}$ & $\begin{array}{c}\text { Settlement } \\
\text { Rate } \\
(\%)\end{array}$ & $\begin{array}{c}\text { Metamor- } \\
\text { phosis } \\
\text { Rate } \\
(\%)\end{array}$ \\
\hline $\begin{array}{cccc}\text { Pseudocentrotus } \\
\text { depressus }\end{array}$ & $0^{*}$ & $<15$ & 0 \\
& 5.6 & 83 & 7 \\
& 10 & 100 & 17 \\
Anthocidaris & 19 & 100 & 37 \\
crassispina & 30 & 100 & 87 \\
& 10 & $<15$ & 0 \\
& 30 & 100 & 83 \\
\hline
\end{tabular}

* Control test.

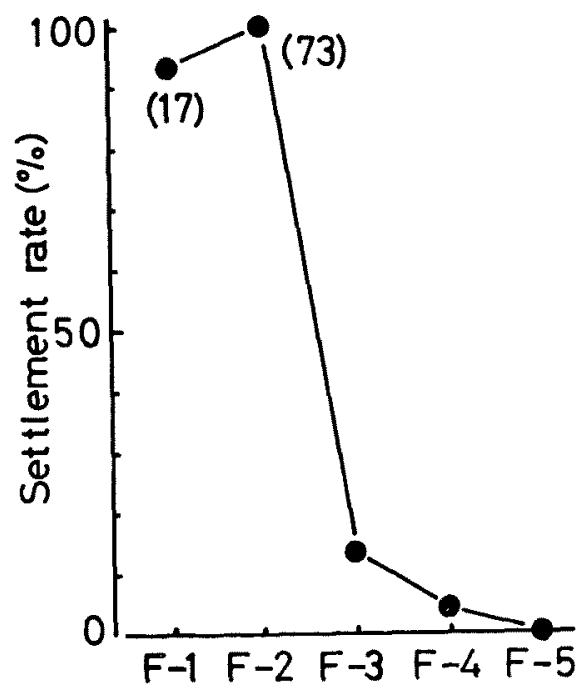

Fig. 1. The settlement rate of Pseudocentrotus depressus larvae induced by fractions from silica gel column chromatography of the lipid extract (30 mg). Weights of F-1 F-5 were 9.0, 2.4, $8.1,7.5$, and $2.6 \mathrm{mg}$ lipid/paper, respectively. The figure in parentheses denotes the metamorphosis rate. The settlement and metamorphosis rates in control tests were always lower than $15 \%$ and $0 \%$, respectively.

$30 \mathrm{mg} /$ paper. Most A. crassispina larvae settled at 10 and $30 \mathrm{mg} /$ paper, the metamorphosis rate at $30 \mathrm{mg} /$ paper being $83 \%$. The effects of the lipid on both larvae grew more pronounced as the amount of lipid increased.

The five fractions obtained by silica gel column chromatography showed similar effects on the settlement and metamorphosis of $P$. depressus and A. crassispina larvae. As shown in Fig. 1, more than $90 \%$ of $P$. depressus larvae settled in response to the $F-1$ and $F-2$ fractions, whereas there was little or on response to fractions $\mathrm{F}-3 \sim$ F-5. The metamorphosis rate for $\mathrm{F}-2$ was $73 \%$, but only $17 \%$ for F-1.

Although some metamorphosed individuals showed deformities, most of the juvenile sea urchins appeared normal. Subsequent growth of metamorphosed juveniles continued normally for more than two weeks, with the diatom Navicula ramosissima, which is one of the suitable primary foods for these sea urchins. ${ }^{\theta}$

\section{Discussion}

Although the metamorphosis rate in benzene extract was $4 \%$, the ether and methanol extracts from the alga $(5 \mathrm{~g})$ induced high levels of both settlement and metamorphosis in both species (Table 1). All larvae settled at more than 10 mg lipid/paper (Table 2). These results clearly suggested that the alga had some lipophilic substances acting as inducers for settlement and metamorphosis of these sea urchin larvae.

The fractions F-1 and F-2 obtained by silica gel column chromatography induced high percentages of larval settlement and metamorphosis in the two species (Fig. 1). TLC showed fractions F-1 and F-2 to contain simple lipids, such as hydrocarbons, triglycerides, and free fatty acids. After consideration of these factors, we concluded that the inducer belongs to the above groups of lipids, because of the inefficiency of settlement and metamorphosis in glycolipid and phospholipid extracted as fractions F-3 F-5.

For further studies, this simple bioassay method is very useful for detection of chemical inducers for larval settlement and metamorphosis of sea urchins.

\section{Acknowledgements}

We wish to express our gratitude to the stam of the fish farming centers in Saga Prefecture and Nagasaki City for providing us with sea urchin larvae. This study was supported in part by a grant from the Research Institute of Marine Invertebrates.

\section{References}

1) Y. Ito; The effect of benthic diatom on the acceleration of the metamorphosis of sea urchin larva. Mar. Foul. 5, 15-18 
(1984)

2) Y. Tani and $Y$. Ito: The effect of benthic diatoms on the settlement and metamorphosis of Pseudocentrotus depressus larva (in Japanese). Suisan Zoshoku, 27, 148-150 (1979).

3) S. Ito, J. Kobayakawa, Y. Tani, and N. Nakamura: The combined effect of Hizikia fusiformis with attaching diatoms for larval settlment and metamorphosis of Hemicentrotus pulcherrimus and Pseudocentrotus depressus (in Japanese). Saibaigiken, 19, 61-66 (1991).

4) R. J. Rowley: Settlement and recruitment of sea urchins (Strongylocentrotus spp.) in a sea-urchin barren ground and a kelp bed: are populations regulated by settlement or postsettlement processes ? Mar. Biol. 100, 485-494 (1989).

5) R. A. Cameron, R. T. Hinegardner: Initiation of metamorphosis in laboratory cultured sea urchins. Biol. Bull. 146, 335-342 (1974).
6) R.A. Cameron and S.C. Schroeter: Sea urchin recruitment: effect of substrate selection on juvenile distribution. Mar. Ecol. Prog. Ser. 2, 243-247 (1980).

7) L.P. Gonzalez, J. C. Castilla, and C. Guisado: Effect of larval diet and rearing temperature on metamorphosis and juvenile survival of the edible sea urchin Loxechinus albus (Molina, 1782) (echinoidea, echinidae). J. Shellfish Res. 6, 109-115 (1987).

8) C. M. Pearce, R. E. Scheibling: Induction of metamorphosis of larvae of the green sea urchin, Strongylocentrotus droebachiensis, by coralline red algae. Biol. Bull. 179, 304311 (1990).

9) Y. Ito, S. Ito, H. Kanamaru, and K. Masaki: Dietary effect of attaching diatom Navicula ramosissima on mass production of young sea urchin Pseudocentrotus depressus. Nippon Suisan Gakkishi, 53, 1735-1740 (1987). 